\title{
Constitutional and legal regulation to make territorial adjustments in the federal stateComparative study in the Indian and Iraqi federal system
}

\author{
Dr.EesmaelNajmadinZangana \\ Faculty of Law/ Cihan University / Sulaymaniyah
}

\begin{abstract}
A federal or federal state is created and created in accordance with a written constitution that is satisfied by the constituent political units, which means that these states are closely linked to the will of the states or states that make up them. The latter occupies a distinct political and administrative position within the federal state within its specific geographical and administrative boundaries. But this determination is not specific indefinitely, but often allows the federal constitution to make changes in these limits, according to constitutional mechanisms and legal difficulty of access to the decision and complexity of actions. Which led us to write this study to find out what these changes and how to conduct in two federal states, Which is an old state and federalism strong and cohesive to a large extent, and the second is Iraq, which in turn is a fledgling federation and it is going over a little more than a decade. The comparison is related to the title of the study, the processes of changes within the boundaries of the states and the region to the results of the study.
\end{abstract}

Keywords: Federal Constitution, Federal State, States, Territory, Constitutional Organization, Legal System, Procedural Mechanisms, Powers, Terms of Reference.

\section{INTRODUCTION}

There is no doubt that the Central State consists of a union of states, provinces or provinces of whatever denomination. These regions maintain their internal independence to a great extent, especially with respect to their geographical borders and the areas to which they belong, especially under the federations formed by accession. Which is to adhere to its borders and land in the strongest.

In fact, most of the world's federal constitutions adopted a different approach to local sentiments when they allowed local and federal elected institutions to make changes in those boundaries by merging two or more states, and authorized decoupling and linking regions of different states, The area of a State at the expense of another State, or the result of the creation of a new territory added to the number of territories constituting the State. Although the countries have left the door close to such changes, the details of the process do not match in all countries, but differ from one model to another. For example, the model of the study (Iraqi and Indian) differ in terms of applying the possibility of changes in the states increase or decrease in theory and practice despite The two communities are pluralistic and have religious, national and sectarian divisions in them.

\section{THE FEDERAL STATE AND ITS MANIFESTATIONS}

We study this section within two main points. The first is devoted to discussing the meaning of the federal state, and the second is the elements of federalism.

\section{The meaning of the federal state}

The term "federalism" means the union or treaty. Which is supposed to be formed between two distinct or more than two sides, to create a combination of them based on the newborn to strong links and multiple points of participation, which in turn stimulate the parties concerned in the search for a formula of a complex composite and solid, federalism in that sense means the movement of individuals Or distinct groups, on the one hand, and the other, on the other hand, towards the formation of a single entity that reconciles the visions of contradictory trends, based on the common 
sense of the need for unity.(Awda. J.)Federalism can be defined by the way in which it is formed. In federalism, federalism is a system that unites a group of countries with common characteristics that combine to form a strong central state that represents them on the international scene and handles defense and security issues National and what the Constitution defines as the federal state. Each Member State shall retain its identity and autonomy. Examples include the United States of America, Switzerland and Canada.(Shali. B. 2014:34). In the event of its formation through the dissolution of a unified state, it is a division of territory into territories, people to peoples, power to powers. That is, the simple division of the State into States without having to create a number of independent States, but to establish a federal State among them, which would collectively represent and exercise some sovereignty over them. Examples include Somalia, Belgium and Sudan.(Awda. J.)

\section{The manifestations of federalism}

The federal state has essential aspects of unity, including independence, the first is the cohesion and union in the federal state, the second is the levels of governance in the state in local areas or regions. And their entirety are necessary for any federal state so we briefly address the manifestations of unity in this part of the study and examine the manifestations of independence in the framework of the second section when dealing with the search of states or regions:

It is divided into two areas, an external field and an internal sphere. In the external sphere, the unitary manifestations are:

- The central State alone shall enter into international relations with other States.

- Only be a member of international organizations

- They shall have the sole right to conclude treaties.

- It shall have sole diplomatic representation.

- It alone has the right to determine war and peace.

- A common nationality shall be established for all citizens of States, where they shall have one nationality.

- The territory of the Union shall be a single unit, covering all the territories of the States members of the Union.

However, this rule is subject to several exceptions: for example: the German Constitution of 1949, which recognized the German Federal Republics the right to conclude treaties with foreign countries within the limits of their jurisdiction and with the consent of the federal government. As for the unifying aspects of internal affairs, Member States lose some of their internal sovereignty in the interest of the Union State, which exercises them in all parts of the Union.

-One Central Constitution The Central Union is based on the Federal Constitution, which defines the terms of reference of each of the central government bodies and bodies of United States governments. It is agreed that this Constitution can be amended only by special procedures provided for in that Constitution.

-A unified central legislative body: The stable rule in the federal state in relation to the composition of the legislature. It is based on the system of the two chambers: the first council (lower council), in which the people of the union are represented in a parliamentary council on the basis of election in a constituency manner. The Supreme Council (the Supreme Council) represents the states on the basis of equality between them regardless of their area or population. However, this rule of equality is not absolute, the constitutions of some countries have emerged and the dependence on representation on the population, such as the Constitution The Mani, who defined the representation of the states with 3 to 5 members due to the density of their population. However, when voting is a collective vote, there is equal voting. In fact, the two chambers of the system requirements of the Federal Union of the need to maintain a balance between the interests of the state and the interests of the US, two councils, one Veugd is a manifestation of unity, and the other is a manifestation of the independence of States.

-A unified executive body: The executive branch of the federal state consists of two branches: the head of state and the federal government: the head of state is usually the president of a republic 
elected by the people, and the direct election of one degree, as in Mexico. The election of two degrees indirectly, as in the United States of America .And the federal government Vti_kl from a number of ministers, and the implementation of federal laws, and the issuance and implementation of federal decisions, and operation of the Federal Public Utilities. The Federal Government implements federal laws and decisions within the state's provinces in three ways: direct management: federal laws and decisions are implemented within states through administrations established by the Union Government and directly subordinate to the states. This method was adopted by the United States Constitution 1787.oslob indirect management: the laws and decisions by various departments of the Federal States competent implementation, due to the lack of establishment of branches of the federal departments in the Alolayat.oppema method took the German Constitution of 1919 .oslob administration of Mixed: based on the basis create some federal departments in the states so that the Federal State officials to implement some laws and decisions that member states assume the task of EU laws and other decisions and implementation. This is the method pursued by the Swiss Constitution in 1874, as well as the Swiss Constitution of 1998.

-The Federal Judicial Unit: It is administered by a Federal Supreme Court. It may be assisted by some federal courts which are distributed throughout the Federal State. It deals with issues of concern to the entire State, such as its competence to adjudicate disputes between the Union and the States or between the various States.

\section{MECHANISMS OF REGIONAL FORMATION.}

The manifestations of independence states or states that constitute the federal state are: the existence of a special constitution for each state. And the existence of public legislative, executive and judicial powers.

\section{The Constitution of the State}

Each State shall have its own constitution regulating its powers and the rights of its citizens. The Constitution shall be construed and modified by its constitutional authority and shall be restricted only by the restrictions established by the Federal Constitution to ensure the unity and public interest of the State. An example of such restrictions is the need to establish state constitutions through popular referenda, the need to apply the principle of separation of powers, and the imposition of the republican system on all internationalities

\section{Powers of the State}

Each State has its own constitutional powers: the legislature, the executive branch and the judiciary.

- Legislature of the mandate: The legislative power is in an elected parliament by the voters of the state to put in place the legislation of the state and control its executive power. Although the legislation of each state complies with the provisions of its constitution and the provisions of the federal constitution, , Which is considered permissible in one state may be prohibited in the other.

- The executive branch of the state: The executive branch of the state is composed of a president and a cabinet in the case of the state's holding of the parliamentary system, or of the president and assistants in the case of the application of the presidential system. The head of state may be elected from the people of his mandate and may be appointed by the federal government. Such an appointment would be more prejudicial to the democratic rule of the state if its constitution embraces the presidential system by giving the ruler broad powers.

- Jurisdiction of the State: Each State shall establish its own tribunals, which shall apply their own laws, to settle disputes between their nationals within the geographical limits of their territorial boundaries.

\section{THE FORMATION OF THE PROVINCES IN INDIA AND IRAQ AND THE CHANGES THERETO}

The Indian Constitution allows the Parliament by law to make changes or amendments to the names and geographical boundaries of the States, but this leave is accompanied by several conditions 
expressly referred to in the Constitution.(Ronald. W. 2006:36-37). Prior to that, the Indian constitutional legislator had done the best when he did not leave the changes that might occur in the states without specifying or representing Apple that he mentioned the common conditions of these amendments:Formation of any new mandate by separating the territory of a territory from any state, by consolidating two or more states or parts of the states, or by merging and unifying any territory with part of any state.

-Increase the area of any state

-Minimize the area of any state

-Change the boundaries of any state

-Change the name of any state

The Constitution has established a fundamental provision in its context that no bill should be submitted for the above-mentioned amendments in either House of Representatives except on the recommendation of the President. If the proposal in the draft law affects the region, The draft law shall then be referred by the President to the legislature of that State to express his or her opinion on that matter within the period specified in the letter of assignment or during such other period as may be authorized by the President, or any time limit specified or permitted before expiration. From these constitutional texts, it is clear that the Indian Parliament can, within the framework of the cases and strips set forth in the Constitution, make adjustments to the borders and names of the Indian Territories without having to refer the matter to a referendum in that context. The Indian Constitution did not omit the regional sense and sense of the States when it required the consent of the legislature of the States affected by the changes to the bill submitted by the President of the Republic.

In Iraq, it is different due to the different federal structure of the state. Iraq does not include practically one territory, Kurdistan Region and all other regions are decentralized governorates subject to the control of the federal central authority and therefore do not have the provinces of independence of the region, which we referred to above.

However, the drafters of the Iraqi constitution have given way to these regions to establish common regions and make changes in their borders, but in terms and conditions less described as complex and difficult and subject to the will of the central authority more submissive.

The Constitution touched on the need to enact a law by the Iraqi Council of Representatives to establish the executive procedures for the formation of the provinces by simple majority, and approved all the provinces the right to form a territory in one of two ways:

1- Requested from one third of the members in each of the provincial councils that intend to form the territory.

2- Request from ten voters in each of the provinces that intend to form the territory.

The Iraqi constitution differs from the Indian constitution in that the first did not recognize the Council of Representatives with a constitutional authority in this area, but the decision to establish a new region be through a local referendum in the provinces, which wants to establish a new province and made the request in that regard .The Iraqi constitution did not explicitly mention the competence of the provinces in the Kurdistan Region or the regions that may be established in the future to apply for accession to a region other than the territory to which it belongs. This is what is required by law No. (13) for the year 2008, which is called the law of executive procedures for the formation of the provinces in Iraq, which added a third way to bring about changes in the regions, when it allowed a governorate to join a region with a request submitted by one third of the members of the provincial councilAs to how to implement the request and take the necessary action, the Iraqi legislator has distinguished between the request be submitted by the parliaments or by the voters:In the case of submission of the request by the quorum required by the vote of the provincial council or the Legislative Council of the Territory, the request for the formation of the region to submit to the Council of Ministers signed by the heads or legal representatives of the provincial councils or legislative councils of the regions as the case in a period not exceeding one week, The High Electoral Commission within a period not exceeding 15 days from the submission of the request to take the referendum procedures within the region to be formed for a period not exceeding three months.

1.If the application is submitted by the quorum required of the voters in the province, the law established a different regulation of the above, where the requirement to submit the application 
starting from $2 \%$ of voters to the Office of the Electoral Commission in the province includes the form of the region to be configured and the Commission to announce that Within three days of submitting the application in newspapers and the media. A minimum period of one month for citizens who satisfy the requirements of the voters shall be stipulated in expressing their wishes supporting the application within a register prepared for that purpose in order to calculate the quorum required.

2.If there are multiple desires about the formation of the new territory then the Office of the Electoral Commission in the province to develop a questionnaire to determine the form of the required regions and presents it to the voters to choose any of them in a period not exceeding two months from the submission of applications and is the form of the region to be submitted to the referendum who gets the most votes Voters participating in the questionnaire.

And then the Electoral Commission through its offices in the provinces or territories to take the referendum procedures and completion within the period of three months set for them and has the right to extend for one month only. The referendum shall be successful if it obtains a majority of the voters from each of the governorates that intend to join a region. The results shall be announced within (15) days of the elections, provided that the percentage of the voters shall not be less than 50\% of the electorate.After the ratification of the final result of the referendum, the decision to form the territory shall be issued by the Prime Minister within a period not exceeding two weeks and the decision shall be published in the Official Gazette. After its publication, the necessary transitional measures are carried out from decentralized administrative units to political and administrative units, and all that is required to travel according to the law.

\section{CONCLUSION}

Having studied the subject of territorial adjustments within the federal state, especially the experiences of India and Iraq, we can review our findings from the study:

1. Amendments to territories in the federal State are constitutional, but in a context and frameworks in which States differ.

2. These changes to regions are often taken with caution by the legislator because of the influence and influence of the local and regional feeling and sensations that bind local regions and regions, which may result from interregional adjustments resulting in different rivalries, strife and dandruff that affect the Union as a cohesive state.

3. The main role in making changes to the Territories, whatever their image is to the Indian Parliament, and in this area enjoyed constitutional authority, while in the Iraqi model, the opinion of the local people is considered a fundamental dissolution of this through a referendum, local and local.

4. In both models, a request is made to make changes in regions or governorates, but the point of difference is that the Indian model is the request submitted by the President of the Republic while in the Iraqi form the request is made by representatives of the local people or of the voters themselves.

5. It seems that the Indian model because of the cohesion of the federal state and the clarity of the federal vision in the levels of government has greatly influenced the more flexible organization of the subject of our study, unlike the Iraqi model, which was the federal will and vision deficient among the framers of the Constitution.

\section{REFERENCES:}

[1] Jamil Awda, The Concept of the Federal State (Views on the thesis of federalism in the new Iraq) Research published at:http://www.siironline.org/alabwab/maqalat\&mohaderat(12)/013.htm.

[2] Bland Ibrahim Hussein Shali, The Relationship between the Federal Government and Local Governments in Federal Systems (Iraq Case Study), Kuristan Center for Strategic Studies, Sulaymaniyah, 2014.

[3] Ronald L. Watts, Federal Regulations, Translated by: GaliBarhoumah, MahaBustami, MahaTakla, Federal Federation Forum, Special Edition, 2006.

[4] The Indian Constitution of 1949.

[5] Constitution of the Republic of Iraq for 2005.

[6] Act of the executive procedures for the formation of the Iraqi provinces No. 13 of 2008. 